\title{
Physicochemical characteristics of unripe and ripe banana 'FHIA 18' submitted to phosphorus fertilizer over three production cycles
}

\author{
Perfil físico-químico de frutos verdes e maduros da bananeira \\ 'FHIA 18' submetida à adubação fosfatada em três ciclos produtivos
}

\author{
Ana Carolina Batista Bolfarini' ${ }^{1}$; Jackson Mirellys Azevêdo Souza'; Fernando \\ Ferrari Putti ${ }^{3}$; Marcelo de Souza Silva ${ }^{1}$; Rafael Bibiano Ferreira ${ }^{1}$; Magali Leonel ${ }^{4}$; \\ Marco Antonio Tecchio5; Sarita Leonel ${ }^{5 *}$
}

\begin{abstract}
The banana fruits of 'FHIA 18' have sensory properties like the 'Prata' ones. However, there is no information regarding to phosphorus $(\mathrm{P})$ requirement of this hybrid and its effects on postharvest quality. This study aims to evaluate the physicochemical properties of 'FHIA 18' banana fruits submitted to different phosphorus levels under the edaphoclimatic conditions of the municipality of São Manuel, state of São Paulo, during three successive production cycles. Therefore, different levels of Phosphorus $(0[0 \%], 20[50 \%)], 30[75 \%], 40[100 \%], 50[125 \%]$ and $60 \mathrm{~kg} \mathrm{ha}^{-1}$ year $\left.^{-1} \mathrm{P}_{2} \mathrm{O}_{5}[150 \%]\right)$ were applied during three production cycles. A completely randomized design and split plot structure was used, the plots consisted of six phosphorus fertilizers doses and three production cycles $(2014,2015$ and 2016) in sub plots. For unripe fruits, we evaluated the contents of dry matter, starch, total sugars, reducing sugars and phosphorus. For ripe fruits, we analyzed firmness, peel colour descriptors, total titratable acidity, total soluble solids, maturity index, total sugars and reducing sugars. Results showed that $\mathrm{P}$ fertilizer provided an increase in P content in unripe fruits until the application of $100 \%$ of the recommended dose; besides an increase in the reducing sugar contents until the application of $61 \%$ over the first production cycle. Results also indicated that applying lower phosphorus doses $(<100 \%$ of the recommended dose) promoted lower total titratable acidity and higher maturity index (52-53\% of recommendation) in ripe fruits. Regardless of $\mathrm{P}_{2} \mathrm{O}_{5}$ dose, the contents of dry matter, starch and phosphorus increased in unripe fruits from first to third crop cycle, as well as the firmness, total soluble solids contents, maturity index and sugar content in ripe fruits.
\end{abstract}

Key words: Musa spp. $\mathrm{P}_{2} \mathrm{O}_{5}$. Mineral nutrition. Starch. Maturation index.

\section{Resumo}

Os frutos da bananeira 'FHIA 18' possuem características sensoriais semelhantes à banana 'Prata', porém, não existem informações sobre as reais necessidades em fósforo $(\mathrm{P})$ deste híbrido e seus efeitos

\footnotetext{
1 Discentes, Curso de Doutorado do Programa de Pós-Graduação em Agronomia/Horticultura, Departamento de Horticultura, Faculdade de Ciências Agronômicas, Universidade Estadual Paulista, UNESP, Botucatu, SP, Brasil. E-mail: anacarolinabolfarini@ hotmail.com; mace-lo-souza@hotmail.com; aprigio bibiano@hotmail.com

2 Pós-Doutorando do Programa de Pós-Graduação em Agronomia/Horticultura, Departamento de Horticultura, Faculdade de Ciências Agronômicas, UNESP, Botucatu, SP, Brasil. E-mail: jackson.mirellys@hotmail.com

3 Prof., Faculdade de Ciências e Engenharia, UNESP, Tupã, SP, Brasil. E-mail: fernando.putti@unesp.br

4 Pesquisadora, Centro de Raízes e Amidos Tropicais, UNESP, Botucatu, SP, Brasil. E-mail: magali.leonel@unesp.br

5 Prof ${ }^{\text {as }}$, Faculdade de Ciências Agronômicas, UNESP, Botucatu, SP, Brasil. E-mail: marco.a.tecchio@unesp.br; sarita.leonel@ unesp.br

* Author for correspondence
} 
na produção e qualidade pós-colheita. O objetivo deste trabalho foi avaliar o perfil físico-químico dos frutos da bananeira 'FHIA 18' submetida à níveis de adubação fosfatada, em São Manuel-SP, durante três ciclos sucessivos. Os níveis de adubação com $\mathrm{P}_{2} \mathrm{O}_{5}$ aplicados foram: sem adubação com $\mathrm{P}(0 \%)$; $20 \mathrm{~kg} \mathrm{ha}^{-1}$ ano $^{-1}(50 \%) ; 30 \mathrm{~kg} \mathrm{ha}^{-1} \mathrm{ano}^{-1}(75 \%) ; 40 \mathrm{~kg} \mathrm{ha}^{-1} \mathrm{ano}^{-1}(100 \%) ; 50 \mathrm{~kg} \mathrm{ha}^{-1}$ ano ${ }^{-1}(125 \%) ; \mathrm{e}$ $60 \mathrm{~kg} \mathrm{ha}^{-1} \mathrm{ano}^{-1}(150 \%)$. Utilizou-se o delineamento inteiramente casualizado, em arranjo de parcelas subdivididas, sendo as parcelas compostas pelos seis níveis de adubação com fósforo e as subparcelas pelos três ciclos de produção (2014, 2015 e 2016). Foram avaliados nos frutos verdes os teores de matéria seca, amido, açúcares totais, açúcares redutores e de fósforo. Nos frutos maduros avaliou-se a firmeza, os descritores de coloração da casca, acidez titulável total, sólidos solúveis totais, índice de maturação, açúcares totais e açúcares redutores. A adubação fosfatada proporcionou aumento nos teores de fósforo nos frutos verdes até a aplicação de $100 \%$ da recomendação e aumento dos teores de açúcares redutores até a aplicação de $61 \%$ no primeiro ciclo de produção. Quanto aos frutos maduros, a utilização de fósforo em doses inferiores às recomendadas (100\%) promoveu menor acidez titulável total e maior índice de maturação (52-53\% da recomendação). Por outro lado, independente da dose de $\mathrm{P}_{2} \mathrm{O}_{5}$ utilizada, os teores de matéria seca, amido e fósforo, nos frutos verdes, e a firmeza, teores de sólidos solúveis totais, índice de maturação e teores de açúcares nos frutos maduros, aumentam do primeiro ao terceiro ciclo de produção.

Palavras-chave: Musa spp. $\mathrm{P}_{2} \mathrm{O}_{5}$. Nutrição mineral. Amido. Índice de maturação.

\section{Introduction}

Banana (Musa spp.) is one of the most important fruit crops of the world. In Brazil, the fruit production is mainly concentrated in cultivars belonging to Prata and Cavendish groups, which have high productive potential, but are susceptible to fungal diseases that are major threats to crops (Pereira et al., 2015).

Therefore, other banana genotypes have been recommended, such as the 'FHIA 18', a tetraploid hybrid (AAAB) developed from crosses between Prata Anã cultivar by the Honduran Foundation for Agricultural Research (FHIA). This hybrid is resistant to Black Sigatoka (Mycosphaerella fijienses) and Panama disease (Fusarium oxysporum f. Sp. Cubense), besides being moderately resistant to Yellow Sigatoka (Mycosphaerella musicola) (Godoy et al., 2016).

Crop yield could be highly improved by fertilizer management that can significantly influence the postharvest quality of fruits. Phosphorus has been frequently mentioned to have preponderant rules on the development, growth and quality of the fruits (Aular \& Natale, 2013), but there is still a paucity of researches directly investigating this nutrient, as most of the researchers' focus are on potassium $(\mathrm{K})$.
Starch synthesis in plants are highly influenced by phosphorus content in their tissue (Park, Baek, Reyes, Yun, \& Hasenstein, 2012; Zhao et al., 2015). Starch is the main source of carbohydrate in unripe bananas, its content varies widely between and within botanical species, even in the same cultivar when grown under different conditions (Mesquita et al., 2016). The use of unripe bananas, as a source of starch, is a solution to the large postharvest losses that occur in the crop's production chain (Leonel, Carmo, Leonel, Franco, \& Campanha, 2011).

Carbohydrate decomposition happens during banana ripening that is marked by the conversion of starch to soluble sugars occurs during fruit development (Adão \& Glória, 2005). Furthermore, bananas' organoleptic properties may change due to the variations in content of starch under the application of $\mathrm{P}$ fertilizers. According to Carvalho, Seccadio, Mourão Júnior and Nascimento (2011), phosphorus deficiency causes abnormal ripening and loss of flavour in bananas, since they tend to reduce sugar content.

In order to determine plants adaptability, cultivars must be evaluated under different cultivation conditions; besides that, postharvest characteristics of banana fruits are crucial to 
analyse the final fruit quality (Godoy et al., 2016). A few studies have evaluated new banana genotypes and their nutritional needs in different soil and climate situations. This kind of research is of great importance, since nutritional requirements of these genetic materials are not equal to traditionally cultivated bananas (Nomura, Cuquel, Damatto, Fuzitani, \& Borges, 2017).

It is deeply significative to the Brazilian economy to study bananas' production systems, while there is a lack of information regarding to phosphorus requirement on 'FHIA 18'. This study aims to evaluate the physicochemical properties of 'FHIA 18 ' banana fruits submitted to different phosphorus levels under the edaphoclimatic conditions of the municipality of São Manuel, state of São Paulo in Brazil, during three successive cycles.

\section{Material and Methods}

\section{Area Characterization}

During all three production cycles (2014, 2015 and 2016), banana plantation was located at São Manuel, state of São Paulo in Brazil (22 44'28'S $48^{\circ} 34^{\prime} 37^{\prime \prime} \mathrm{W}$, at an altitude of $740 \mathrm{~m}$ ). The climate is humid subtropical $(C f a)$, that is, temperate hot (mesothermic), with concentrated rains from November to April (summer) and average annual rainfall of $1,376.70 \mathrm{~mm}$; the city's average temperature of the warmest month exceeds $22^{\circ} \mathrm{C}$ (Cunha \& Martins, 2009). In a dryland system, bananas trees were planted with a spacing of $2.5 \mathrm{~m}$ between rows and $2.5 \mathrm{~m}$ between plants in Red Latosol.

\section{Phosphate fertilization}

Prior to experiment, soil samples were collected in subplots at a $0-20 \mathrm{~cm}$ soil depth to determine soil chemical analysis, results indicated $\mathrm{pH}\left(\mathrm{CaCl}_{2}\right)$ 5.5; O.M.,12 $\mathrm{g} \mathrm{dm}^{-3}$; Presin, $16 \mathrm{mg} \mathrm{dm}^{-3} ; \mathrm{H}+\mathrm{Al}, 15 \mathrm{mmol}$ $\mathrm{dm}^{-3}$; K, $1 \mathrm{mmol}, \mathrm{dm}^{-3}$; Ca, $13 \mathrm{mmol}, \mathrm{dm}^{-3} ; \mathrm{Mg}, 5$ mmol, dm ${ }^{-3}$; SB, $19 \mathrm{mmol}, \mathrm{dm}^{-3}$; CTC, $34 \mathrm{mmol}$, $\mathrm{dm}^{-3} ; 57 \% \mathrm{~V} ; \mathrm{S}, 1 \mathrm{mg} \mathrm{dm}^{-3} ; \mathrm{B}, 0.30 \mathrm{mg} \mathrm{dm}^{-3} ; \mathrm{Cu}$, $0.86 \mathrm{mg} \mathrm{dm}^{-3} ; \mathrm{Fe}, 20 \mathrm{mg} \mathrm{dm}^{-3} ; \mathrm{Mn}=13 \mathrm{mg} \mathrm{dm}^{-3}$; and $\mathrm{Zn}=1.40 \mathrm{mg} \mathrm{dm}^{-3}$. Therefore, the recommendation pattern of $\mathrm{P}$ fertilizer was estimated at $100 \%$, according to soil chemical analysis and expected yield less than $20 \mathrm{t} \mathrm{ha}^{-1}$ (Teixeira, Nomura, Damatto, \& Fuzitani, 2014).

The fertilizer strategies used were as follows: $\mathrm{D} 1=$ no application (control); D2 $=50 \%$ of the recommended dose $\left(20 \mathrm{~kg} \mathrm{P}_{2} \mathrm{O}_{5}\right.$ ha $^{-1}$ year $\left.^{-1}\right) ; \mathrm{D} 3=$ $75 \%$ of the recommended dose $\left(30 \mathrm{~kg} \mathrm{P}_{2} \mathrm{O}_{5}\right.$ ha $^{-1}$ year $\left.^{-1}\right) ; \mathrm{D} 4=100 \%$ of the recommended dose $(40 \mathrm{~kg}$ $\mathrm{P}_{2} \mathrm{O}_{5}$ ha $^{-1}$ year $\left.^{-1}\right) ; \mathrm{D} 5=125 \%$ of the recommended dose $\left(50 \mathrm{~kg} \mathrm{P}_{2} \mathrm{O}_{5}\right.$ ha $^{-1}$ year-1 $) ; \mathrm{D} 6=150 \%$ of the recommended dose $\left(60 \mathrm{~kg}_{2} \mathrm{O}_{5}\right.$ ha $^{-1}$ year $\left.^{-1}\right)$. Furthermore, triple superphosphate (46\% P2O5) was used as the source of phosphorus.

Phosphate fertilization was performed according to recommendations proposed by Teixeira et al. (2014), that is, half of $\mathrm{P}$ doses were directly applied into the planting plots, while the remainder were applied in $100 \mathrm{~cm}$ circles around the plants at 80 days after planting. In the first, second and third production cycle, the application of $\mathrm{P}_{2} \mathrm{O}_{5}$ doses maintained the appropriate percentages of evaluations $(0,50,75$, 100,125 and $150 \%$ of the recommended dose), being divided into three applications, as topdressing fertilization, in a semicircle form of $100 \mathrm{~cm}$ radius right in front of the youngest shoots.

\section{Crop management practice and complementary fertilization}

The banana trees were conducted to compose a "family", i.e. mother plant (first cycle), daughter plant (second cycle) and granddaughter plant (third cycle). According to crop recommendations and previous soil analysis (Teixeira et al., 2014), topdressing and production fertilization were also applied by using ammonium sulphate and potassium chloride, as nitrogen (N) and potassium (K) source, respectively. 


\section{Harvesting banana bunches}

In each crop cycle, seven bunches were harvested per experimental plot, when fruits of the second hand presented a diameter of at least $36 \mathrm{~mm}$, that is, the harvest point established for Prata cultivars, corresponding to the first maturity stage (green peel), according to Von Loesecke's maturity scale (Companhia de Entrepostos e Armazéns Gerais de São Paulo [CEAGESP], 2006). The banana bunches were plummeted; then, the second, third and fourth hands were selected.

\section{Physicochemical characterization of unripe fruits}

Twelve fruits from the first maturity stage were randomly selected immediately after harvest in the third and fourth hands, according to Von Loesecke's maturity scale (CEAGESP, 2006). Therefore, fruits were left to rest on absorbent paper for a few minutes, peeled and sliced; then, a sample was taken for moisture analysis. The content of pulp dry matter was determined gravimetrically in seven samples per treatment (Association of Official Analytical Chemists [AOAC], 2007).

All the rest of the green fruits pulp was placed in trays and taken to a fruit drying kiln with forced air circulation at $50^{\circ} \mathrm{C}$ for 48 hours. After dehydration, the slices were ground in a rotary knife mill. Then, the following evaluations were performed: total and reducing sugar contents (Nelson, 1944); starch content, determined by the enzymatic hydrolysis method (ISO-6647) (International Organization for Standardization [ISO], 1987); and phosphorus content, determined in four samples per treatment, according to Malavolta, Vitti and Oliveira (1997).

\section{Physicochemical characterization of ripe fruits}

The second hands of the seven bunches per treatment were used to evaluate the postharvest quality of the ripe banana. Fruits were kept in benches exposed to room temperature, until full ripening. When the five central fruits of the hands reached maturity stage $6(100 \%$ yellow peel), according to the Von Loesecke scale (CEAGESP, 2006), the following evaluations were performed:

- Peel colour descriptors: determined with the aid of the Konica Minolta CR-300 Chroma Meter (Konica Minolta Sensing, Inc.), the results expressed in terms of colour space L* a* b* (CIElab scale), hue angle, and chroma value; where $\mathrm{L}$ indicates brightness, $\mathrm{a}^{*}=\mathrm{red} / \mathrm{green}$ coordinate $(+\mathrm{a}$ indicates red and $-\mathrm{a}$ indicates green) and $\mathrm{b}^{*}=$ yellow/blue coordinate $(+\mathrm{b}$ indicates yellow and $-\mathrm{b}$ indicates blue). Then, the values of $a^{*}$ and $b^{*}$ determined the hue angle $\left(\mathrm{h}^{\circ}\right)$ and chromaticity $\left(\mathrm{C}^{*}\right)$, according to the following equations $\mathrm{h}^{\circ}=\tan -1\left(\mathrm{~b}^{*} / \mathrm{a}^{*}\right)$ and $\mathrm{C}^{*}=$ $\left(a^{* 2}+b^{* 2}\right) 0.5$. The ${ }^{\circ} \mathrm{h}$ indicates the colour tone and the $\mathrm{C} *$ indicates the colour intensity.

- Firmness was obtained with the aid of texturometer (TA. XT Plus Texture Analyzer) with SMS P/2 needle probe (Stable Micro Systems) and a speed test of $2.0 \mathrm{~mm} \mathrm{~s}^{-1}$.

- Total Titratable Acidity (TTA) was based on the method proposed by Instituto Adolfo Lutz [IAL] (2008).

- Total soluble solids (TSS) were quantified by a refractometry and the result shown in Brix degree ( ${ }^{\circ}$ Brix) by reading an aliquot of the homogenized pulp.

- Maturity index (MI): obtained through the ratio between total soluble solids content and total titratable acidity.

- Content of total and reducing sugars (Nelson, 1944).

\section{Experimental design and statistical analysis}

A completely randomized design and split plot structure was used with ten useful FHIA 18 hybrid plants per experimental plot. The plots consisted of six phosphorus fertilizers doses and three crop cycles $(2014,2015$ and 2016) in sub plots 
The analysis of variance was used to verify treatment effects on the assessed traits; and, when significant effects were detected, the regression analysis was performed for the factor doses; in addition to the Tukey test for the factor production cycle by estimating error probability from 1 to $5 \%$. All analyses were done using Statistical Analysis System Computer (SISVAR) (Ferreira, 2011).

\section{Results and Discussion}

Physicochemical characterization from unripe fruits of bananas

Results only indicated a significant interaction effect on reducing sugar content $(p \leq 0.01)$, allowing us to infer that such trait varied, due to the different $\mathrm{P}$ doses applied in each production cycle. Although the phosphorus content in fruits did not vary according to the production cycles, since $\mathrm{P}$ fertilizer acted in isolation $(p \leq 0.01)$. Moreover, there was some isolated effects on the contents of moisture; dry matter and starch $(\mathrm{p} \leq 0.05)$; total sugars and $\mathrm{P}$ in the fruit $(p \leq 0.01)$ for the factor production cycle.

Regarding to the reducing sugars, the maximum content $(1.07 \%)$ was reached by applying $61 \%$ of the recommended dose $\left(24.4 \mathrm{~kg}\right.$ of $\mathrm{P}_{2} \mathrm{O}_{5}$ ha $^{-1}$ year ${ }^{1} \mathrm{~kg}$ ) in the first crop cycle, that is, an increase of $18.9 \%$ when compared to control. While this trait was not affected by the different $\mathrm{P}$ doses in the subsequently cycles, since it averaged out over the second $(1.00 \%)$ and third production cycle $(0.89 \%)$ (Figure 1). Results showed that the availability of $\mathrm{P}$ in soil increased from the beginning of the experiment $\left(16 \mathrm{mg} \mathrm{dm}^{-3}\right)$ to $\mathrm{P}$ fertilizer applications, promoting changes in the deposition of reducing sugars in the 'FHIA 18' unripe fruits. This outcome may have occurred because carbohydrates synthesis in plants are influenced by $\mathrm{P}$ content in plant tissue, which is confirmed by Park et al. (2012), who found that the lowest application of $\mathrm{P}$ fertilizer decreases glucose biosynthesis. After the first cycle, the lack of response to $\mathrm{P}$ is due to the increase in root system, which may have enabled the absorption of $\mathrm{P}$ in deeper soil layers, as the cycles progress (J. T. A. Silva \& Rodrigues, 2013). Moreover, banana trees become interdependent, when the clump is established, that is, one plant can absorb nutrients through other plant's root system (Kurien, Kumar, Kamalam, \& Wahid, 2006).

Results also presented higher averages of reducing sugar contents in the first and second production cycle; however, the lowest content received $150 \%$ of the recommended dose $(60 \mathrm{~kg}$ of $\mathrm{P}_{2} \mathrm{O}_{5}$ ha $^{-1}$ year ${ }^{-1} \mathrm{~kg}$ ) in the first production cycle $(0.63 \%)$, compared to the 1.09 and $0.89 \%$ in the second and third cycle, respectively (Figure 1).

For unripe bananas, the increase in reducing sugar content to the estimated level of $\mathrm{P}$ is unwanted for flour production in food processing industry, as high reducing sugar levels darkened banana through heating process, due to the Maillard reaction or non-enzymatic browning that occurs between reducing sugars and amino acids (Mohamed, $\mathrm{Xu}$, $\&$ Singh, 2010). However, the average levels of reducing sugars $(0.94 \%)$ in the first cycle remained at adequate levels, because sugar levels in unripe bananas vary from 1-2\% (Chitarra \& Chitarra, 2005), such variation is due to the intrinsic metabolic characteristics of the cultivar and cultivation conditions. 


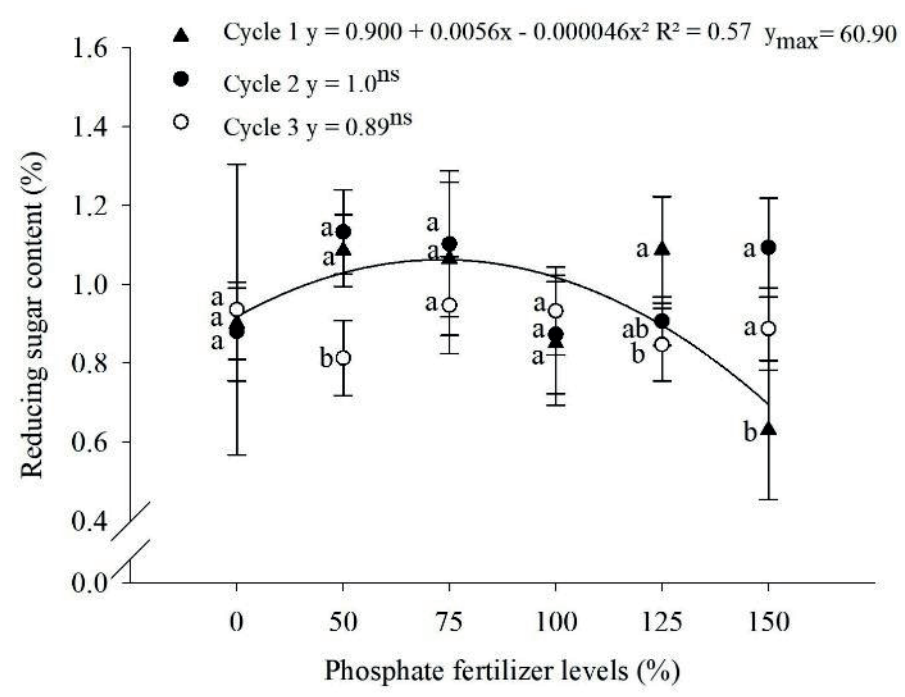

Figure 1. Reducing sugar content in 'FHIA 18' (AAAB) banana fruits, as a response to $\mathrm{P}$ fertilizer over three production cycles. FCA / UNESP, Sao Manuel-SP, 2018.

Equal letters between cycles do not differ by the Tukey test at 5\% probability level. Error bars have $n=7 . Y_{\max }$ is the determination of the maximum reducing sugar content in which the first derivative of the adjusted quadratic regression was equalled.

Nevertheless, moisture and dry matter contents were only affected by the production cycle, indicating that $\mathrm{P}$ fertilizer does not interfere with the percentage of dry matter in 'FHIA 18' banana fruits, which is an important quality parameter for food industries, as it affects yield in the preparation of concentrated and/or dehydrated products, such as flour made from green bananas that has been largely used in several innovative products, e.g. slowly digestible cookies, high-fibre bread and edible food packaging (D. A. S. B. Oliveira, Müller, Franco, Kotovicz, \& Waszczynskyj, 2015). Even P fertilizer did not promote any significant changes in fruit moisture content and, therefore, did not change dry matter content, it can be inferred that yield of concentrated and/or dehydrated food products from them will not be modified.

The highest percentages of dry matter were obtained in the third production cycle (Table 1) that is also related to the higher starch content found in this cycle, as 70 to $80 \%$ of the pulp dry matter in unripe banana is constituted by starch, which is mainly composed of two polymers, i.e. amylose and amylopectin, the latter being highly branched polymer, with a high molecular weight (Jane, 2006).

Production cycles also affected total sugar and starch contents, since the first (1.32\%) and second cycle $(1.33 \%)$ presented the highest averages of total sugar contents, while the third cycle registered the lowest average (1.12\%). Regarding to the starch content, the third cycle performed the highest content (26.96\%) (Table 1); therefore, showing an inverse relationship between total sugar and starch contents in 'FHIA 18'. In unripe bananas, the pulp has no flavour, but a starchy mass with low sugar and aromatic compounds (D. A. S. B. Oliveira et al., 2015). 
Table 1

Average values of moisture, dry matter, total sugars, starch and phosphorus in 'FHIA 18' (AAAB) banana fruits, in the first, second and third production cycle in São Manuel, state of São Paulo

\begin{tabular}{cccccc}
\hline Cycles & Moisture (\%) & Dry matter (\%) & Total sugars $(\%)$ & Starch $(\%)$ & P in fruit $\left(\mathrm{g} \mathrm{kg}^{-1}\right)$ \\
\hline First & $64.91 \mathrm{ab}$ & $35.09 \mathrm{ab}$ & $1.32 \mathrm{a}$ & $24.87 \mathrm{~b}$ & $0.88 \mathrm{~b}$ \\
Second & $66.02 \mathrm{a}$ & $33.98 \mathrm{~b}$ & $1.33 \mathrm{a}$ & $24.79 \mathrm{~b}$ & $0.98 \mathrm{a}$ \\
Third & $64.39 \mathrm{~b}$ & $35.61 \mathrm{a}$ & $1.12 \mathrm{~b}$ & $26.96 \mathrm{a}$ & $0.99 \mathrm{a}$ \\
\hline DMS & 1.25 & 1.25 & 0.15 & 1.86 & 0.04 \\
\hline
\end{tabular}

Means followed by the same lowercase letters are not significantly different, according to the Tukey test $(\mathrm{p} \leq 0.05)$.

The higher starch content observed in the third production cycle may be related to the higher banana yields, as there was an increase in fruit mass over the cycles, according to J. T. A. Silva and Rodrigues (2013). This higher plant vigour is associated with higher photosynthetic efficiency during the third cycle, because even with increased production, there is a higher carbohydrate reserve (Taiz, Zeiger, Møller, \& Murphy, 2017). Besides that, the higher yield and, consequently, the higher starch content, can be attributed to the greater nutrients' availability over the cycles course (Nomura et al., 2017; Kurien et al., 2006). In addition, starch and sugar contents in fruits depend on climatic conditions in which banana trees are growing (L. P. Silva \& Moreira, 2005; Souza, Leonel, Martins, \& Segtowick, 2013; Leonel et al., 2011), since temperature and water availability act directly on the photosynthetic and respiratory activity of banana trees.

Although P fertilizer could lead to variations in the total sugar content, as adequate phosphorus intake tends to provide energy for the metabolic processes (Park et al., 2012); consequently, increasing sugar synthesis. Finally, results demonstrated that the mean values $(1.26 \%)$ remained at normal levels (Chitarra \& Chitarra, 2005).

Furthermore, there are also some indications that $\mathrm{P}$ interferes with synthesis and deposition of starch in some cultures (Rosen, Kelling, Stark, \& Porter, 2014; Zhao et al., 2015; A. P. Oliveira, Silva, Pereira, $\&$ Barbosa, 2005); however, this behaviour was not observed in this study. The starch of unripe banana has immense agricultural and industrial potential, due to its interesting applicability characteristics for food industry, such as significant levels of amylose; high peak and final viscosity; and high in resistant starch (Leonel et al., 2011; Mesquita et al., 2016).

$\mathrm{P}$ fertilizer increased $\mathrm{P}$ content in fruits, being the maximum estimated content of $0.96 \mathrm{~g} \mathrm{~kg}^{-1}$ with $100 \%$ of the recommended dose $\left(39.80 \mathrm{~kg}\right.$ of $\mathrm{P}_{2} \mathrm{O}_{5}$ ha $^{-1}$ year ${ }^{-1}$ ) (Figure 2). P stimulates banana root growth and provides greater nutrient availability for plants, when its content is balanced from the beginning of vegetative development (Mustaffa \& Kumar, 2012), which may lead to high mineral contents in the fruit pulp, such as P.

When phosphate groups are covalently bonded to native starch granules, they can aid the water molecules incorporation, due to their ionic organization; besides modifying the starch's functional properties, such as gelatinization, retrogradation, viscosity and swelling power (Mesquita et al., 2016). In addition, high phosphorus content in starch may be associated with poor digestibility, as its structural organization in the granule prevents enzymatic action under phosphorylated starch; thus, delaying carbohydrate absorption and resulting in lowerglycaemic response, which is desirable for overweight individuals or who has blood glucose above the maximum limit established (Absar et al., 2009). Therefore, higher levels of phosphorus in fruits and, consequently, in starches are of great importance for the applicability of unripe bananas in food industries. 


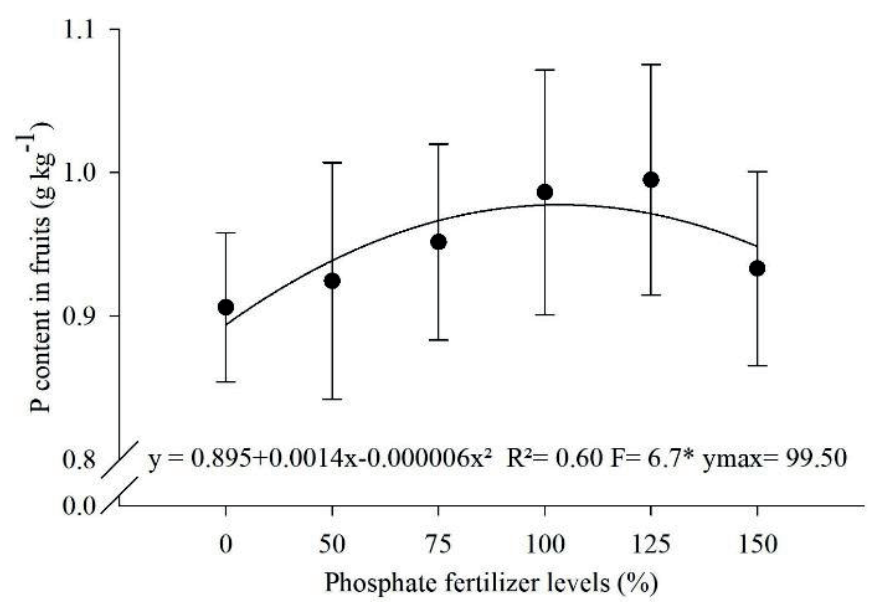

Figure 2. Phosphorus content in 'FHIA 18' (AAAB) banana unripe fruits, as a response to $\mathrm{P}$ fertilizer. FCA/UNESP, São Manuel, state of São Paulo, 2018.

Error bars have $n=4 . Y_{\max }$ is the determination of the maximum phosphorus content in fruits, in which the first derivative of the adjusted quadratic regression was equalled.

The average levels of $\mathrm{P}$ in fruits were significantly higher in the second and third production cycle $(0.98$ and $0.99 \mathrm{~g} \mathrm{~kg}^{-1}$ ), when compared to the first one (Table 1). These results confirm that root increment increased nutrient availability to the whole plant, especially in relation to phosphate ions, since its absorption is often related to root length (Attia, Ahmed, \& El-Sonbaty, 2009), as there was an increase in banana root system over the production cycles (J. T. A. Silva \& Rodrigues, 2013); thus, enabling higher absorption and phosphorus contents in fruits that were produced in the second and third cycle. From the second cycle on, there was a greater accumulation and translocation of nutrients between daughter plant and granddaughter plant, that is, when the clump was established (Kurien et al., 2006).

\section{Physicochemical characterization from ripe fruits of banana}

Results indicated that there was no interaction of the studied factors (i.e. P fertilizer and production cycles). When analysed separately, it was found significance of $\mathrm{P}$ levels for total titratable acidity $(p \leq 0.01)$ and maturity index $(p \leq 0.01)$. The factor of production cycles was significant $(p \leq 0.01)$ for firmness, total soluble solids, maturity index, total titratable acidity and reducing sugars; the latter demonstrated variations over production cycles due to climatic conditions, genetic potential and nutrient availability in the soil; consequently, interfering in postharvest quality of the 'FHIA 18 '.

Regarding to the peel colour descriptors that was evaluated in ripe fruits during first productive cycle, it was found that the levels of $\mathrm{P}$ fertilizer affected significantly $(\mathrm{p} \leq 0.05)$ both $\mathrm{a}^{*}$ coordinate and hue angle. Whilst the averages of the following coefficients were not affected: luminosity (63.37), $b^{*}$ coordinate (42.79) and chroma (43.14).

There was a negative linear effect of $P$ fertilizer on the $\mathrm{a}^{*}$ coordinate. This result indicates the presence of the red component in greater intensity in the peel of ripe bananas from control treatment, which in turn led to the positive linear effect on 
the hue angle $\left(\mathrm{h}^{\circ}\right)$, since these colour parameters are inversely proportional (Figure 3). The higher the intensity of the red colour, the more mature the fruits; while the lower values of the coordinate $\mathrm{a}^{*}$ may indicate the greater presence of chlorophyll. In other words, it is possible to infer that $\mathrm{P}$ fertilizer may have slowed fruit ripening, which is confirmed by the higher acidity levels in fruits at the highest P dose.

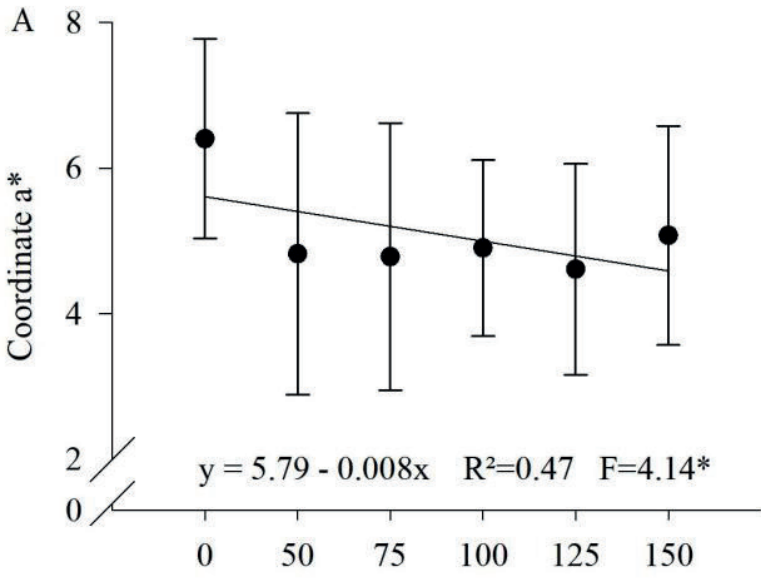

Phosphate fertilizer levels (\%)

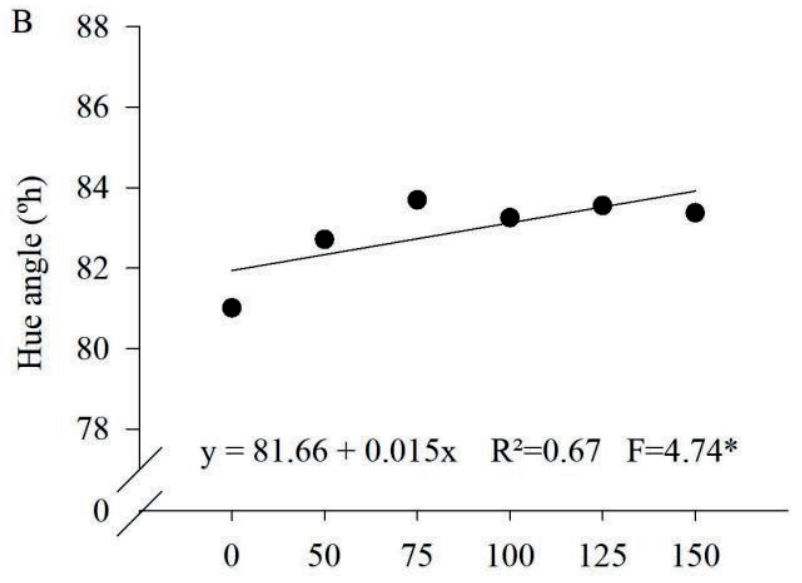

Phosphate fertilizer levels (\%)

Figure 3. Peel colour, coordinate $\mathrm{a}^{*}(\mathrm{~A})$ and hue angle $\left({ }^{\circ} \mathrm{h}\right)(\mathrm{B})$, in the ripe fruits of 'FHIA 18' (AAAB), as a response to P fertilizer. FCA / UNESP, São Manuel, state of São Paulo, 2018.

Error bars have $\mathrm{n}=7$.

Phosphorus interference on colour parameters in fruit peels has been reported by some authors, which justify a possible relationship of this effect on pigment synthesis and dry matter content in pulp (Li, Gemma, \& Iwahori, 2002; Martuscelli et al., 2016).

Over the two first production cycles, the firmness of ripe fruits presented average values of 1.37 and $1.57 \mathrm{~N}$, respectively (Figure 4); but also, no evidence of $\mathrm{P}$ fertilizer effect, probably due to the absence of this effect on the percentage of dry matter in the fruits. Research evaluating the influence of $\mathrm{P}$ fertilizer on the firmness of some fruits also indicated the lack of response to $\mathrm{P}$ (Neilsen, Neilsen, \& Toivonen, 2008; Medeiros, Andrade, Pereira, Mendonça, \& Fonseca, 2014; A. C. Silva et al., 2016). However, firmness values are adequate for 'Prata' bananas at maturity stage 6, as Damatto et al. (2005), featured fruits of
'Prata Anã' and 'Prata-Zulu' during ripening stages, reported average values of $1.58 \mathrm{~N}$ for ripe fruits. The highest firmness observed in the second production cycle can be attributed to climatic conditions and fruit nutrient availability, which vary throughout the cycles. According to Pereira et al. (2015), fruits with greater firmness are less susceptible to plummeting. Therefore, the increase in this variable is interesting, especially in relation to 'FHIA 18', which present problems with the natural fruits' detachment.

$\mathrm{P}$ fertilizer promoted a quadratic decrease of the total titratable acidity in fruits. The estimated minimum acidity value $(0.55 \%)$ was obtained with $52 \%$ of recommended dose $\left(20.60 \mathrm{~kg}\right.$ of $\mathrm{P}_{2} \mathrm{O}_{5}$ ha $^{-1}$ year $^{-1}$ ) (Figure 5). The decrease in fruit acidity to an estimated $\mathrm{P}$ dose, is related to the higher yield (data not shown) achieved with such doses; the more the increase in fruit production are, the greater the 
organic acids dilution in banana cell vacuoles have. dose promoted higher banana yield and lower fruit Consequently, the tendency to increase acidity acidity percentages. Although, the highest acidity due to higher levels of $\mathrm{P}$ fertilization is associated content was also observed in treatments where the with lower yield. According to Attia et al. (2009), lowest yield was obtained in bananas.

the use of bacteria with $25 \%$ of the commercial $\mathrm{P}$

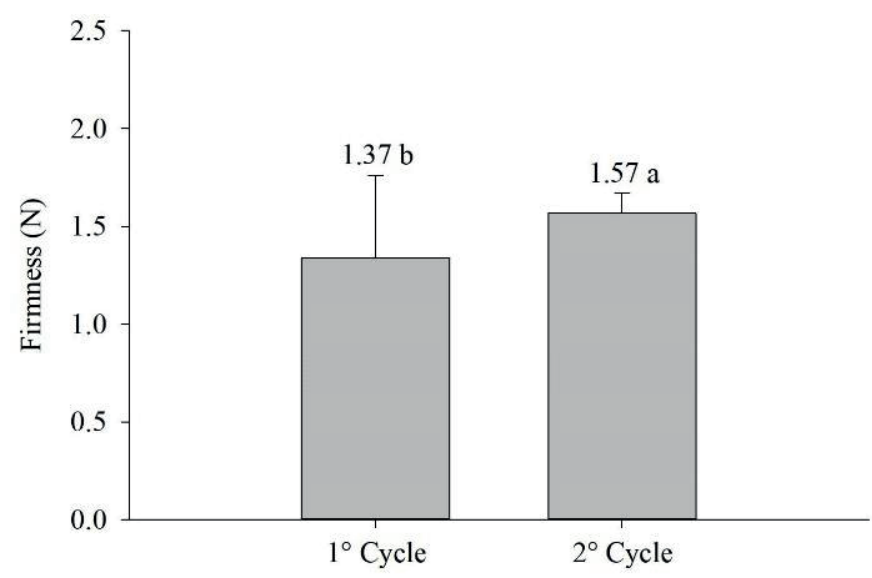

Figure 4. Firmness in ripe banana fruits 'FHIA 18' (AAAB) over the first and second production cycle in São Manuel, state of São Paulo.

Error bars have $\mathrm{n}=7$.

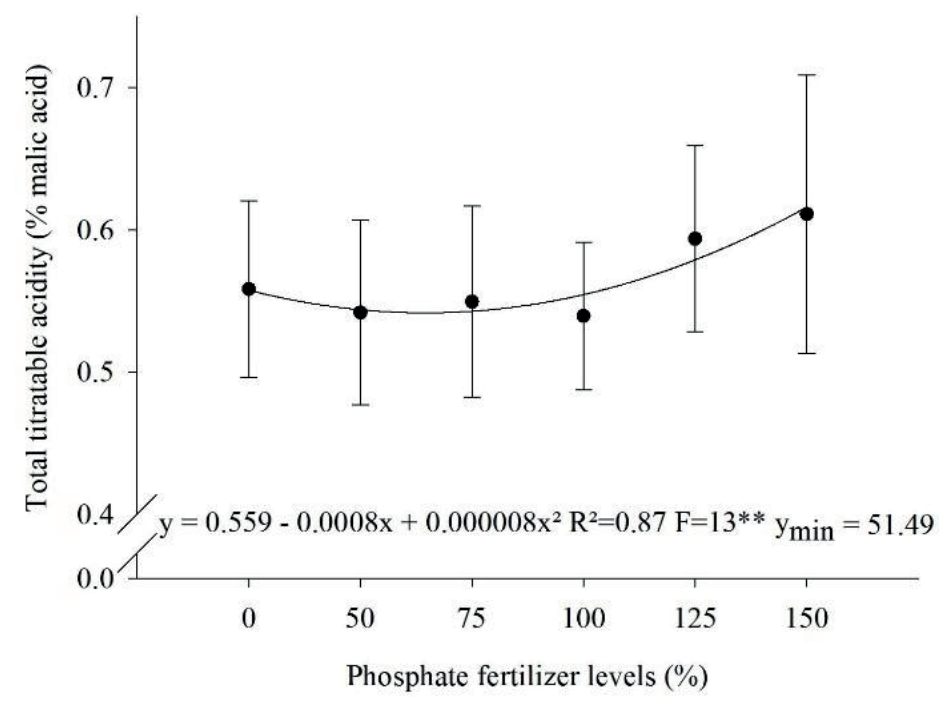

Figure 5. Total titratable acidity (\% malic acid) in 'FHIA 18 ' (AAAB) banana ripe fruits, as a response to P fertilizer. FCA / UNESP, São Manuel, state of São Paulo, 2018.

The error bars have $n=7 . Y_{\min }$ is the determination of the minimum titratable total acidity in which the first derivative of the adjusted quadratic regression was equalled. 
Regarding to the outcomes obtained from peel colour descriptors, it may lead to a hypothesis of ripening deceleration at the highest $\mathrm{P}$ dose, according to the higher acidity observed in fruits.

It could be interesting to decrease fruit acidity until certain levels of $\mathrm{P}$ fertilizer, especially for 'FHIA 18', as this cultivar has higher acidity, when compared to other 'Prata' type bananas (Castricini, Santos, Deliza, Coelho, \& Rodrigues, 2015). It is highly important to consumer market acceptance, since banana is mainly influenced by its chemical composition, such as acids, sugars and phenolic compounds. In an experiment conducted by Souza et al. (2013), the lowest consumption preference of bananas was also the one with the highest acidity percentage. Banana's main organic acid is the malic acid, which is close to $0.32 \%$ in Cavendish group and $0.66 \%$ in 'Prata' group (Nascimento, Ozorio,
Rezende, Soares, \& Fonseca, 2008). The minimum acidity value found in the current study $(0.55 \%)$ is close to that reported by O. C. G. Oliveira, Donato, Mizobutsi, Silva, \& Mizobutsi (2013) for 'Prata Anã' $(0.54 \%)$, which is related to 'FHIA 18 ' and presents good market acceptance for its typical 'Prata' banana flavour.

Although no changes were observed in the total soluble solids content as a function of phosphorus application, the maturity index was significantly influenced by $\mathrm{P}$ fertilizer, since this qualitative parameter is inversely proportional to acidity. Therefore, maturity index enhanced quadratically to increasing levels of $\mathrm{P}$, reaching the maximum estimated value of 43.27 with $53 \%$ of the recommended dose $\left(21.1 \mathrm{~kg}\right.$ of $\mathrm{P}_{2} \mathrm{O}_{5}$ ha $^{-1}$ year $\left.{ }^{-1}\right)$ (Figure 6).

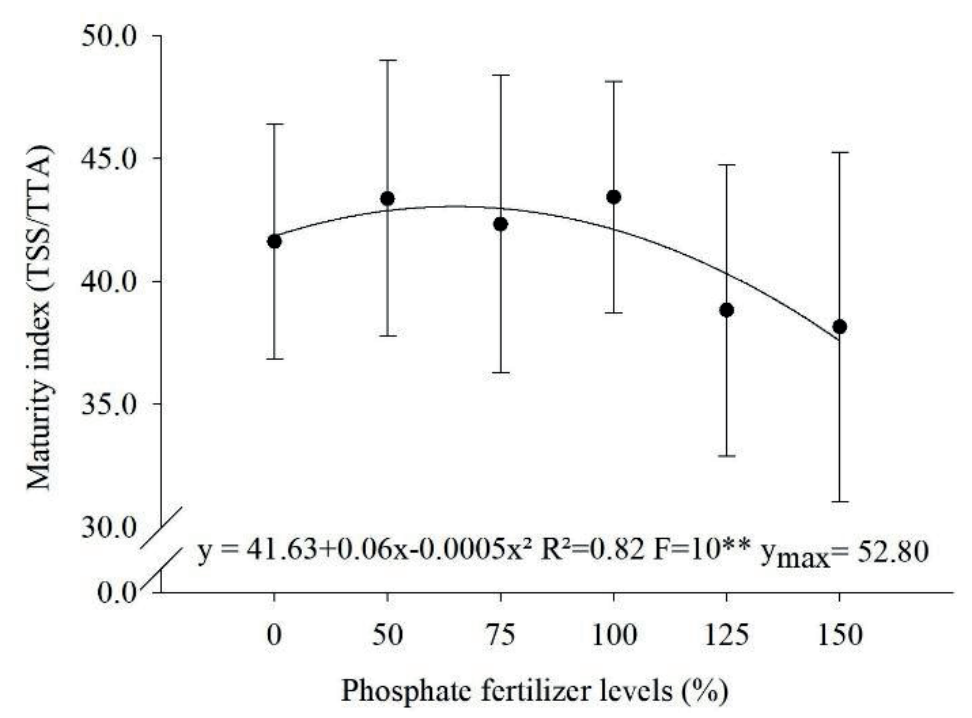

Figure 6. Maturity index in the ripe fruits of 'FHIA 18' (AAAB) banana, as a response to P fertilizer. FCA / UNESP, São Manuel, state of São Paulo, 2018.

The error bars have $n=7 . Y_{\max }$ is the determination of the maximum maturity index at which the first derivative of the adjusted quadratic regression was equalled. 
Maturity index also serves as an important indicator of consumer preference, as flavour attributes are the most important when choosing and buying bananas, along with the expectation of shelflife and general appearance (Siqueira, Almeida, Serpa, Batista, \& Mizobutsi, 2017), since fruits with higher maturity index tend to allow greater perception of sweetness.

When maturity index is increased by the optimum $\mathrm{P}$ dose, it reveals the amount of total soluble solids that overlapped total titratable acidity; thus, the sweet taste expression becomes more evident in bananas produced under this fertilization. Among fruit quality aspects, the flavour of banana is one of the most important and is related to the sugar content in fruits. In this study, the maximum value of the maturity index was higher than the average value of 42.20 that was obtained by Roque, Amorim,
Ferreira, Ledo, \& Amorim, (2014) on 'FHIA 18' at consumption point, as well as the value of 39.15 obtained by Godoy et al. (2016).

The contents of total soluble solids, total and reducing sugars were not influenced by $\mathrm{P}$ fertilizer, due to the absence of its effect on starch content in unripe fruits, as starch is degraded to soluble sugars (mainly sucrose, glucose and fructose) when fruits ripen (Adão \& Gloria, 2005). Although some other compounds (acids, vitamins, amino acids and pectin) are part of the total soluble solids content, most are sugars.

During the third production cycle, the highest levels of total soluble solids, total sugars and reducing sugars in ripe fruits (Table 2) lead to the hypothesis of higher photosynthetic efficiency and nutrient availability; consequently, highest levels of starch.

\section{Table 2}

Average values of total soluble solids, maturity index (TSS/TTA), total sugars and reducing sugars in ripe fruits of 'FHIA 18' (AAAB) banana over the first, second and third production cycle in São Manuel, state of São Paulo

\begin{tabular}{ccccc}
\hline Cycles & Total Soluble Solids $\left({ }^{\circ}\right.$ Brix $)$ & Maturity index (TSS/TTA) & Total Sugars (\%) & Reducing Sugars (\%) \\
\hline First & $21.98 \mathrm{c}$ & $39.03 \mathrm{~b}$ & $17.79 \mathrm{~b}$ & $16.68 \mathrm{~b}$ \\
Second & $23.19 \mathrm{~b}$ & $42.51 \mathrm{a}$ & $17.08 \mathrm{~b}$ & $16.09 \mathrm{~b}$ \\
Third & $23.67 \mathrm{a}$ & $42.33 \mathrm{a}$ & $19.54 \mathrm{a}$ & $18.80 \mathrm{a}$ \\
\hline DMS & 0.42 & 2.40 & 0.76 & 0.68 \\
\hline
\end{tabular}

Means followed by the same lowercase letters are not significantly different according to the Tukey test $(p \leq 0.05)$.

The total soluble solids contents obtained in the first and second cycle were higher than those reported by Roque et al. (2014), which obtained averages of 19.92 (first cycle) and $20.57{ }^{\circ}$ Brix (second cycle) for 'FHIA 18' at maturity stage 6 . While Castricini et al. (2015) reported an average content of $22.9^{\circ}$ Brix for ripe bananas of the same cultivar. The total soluble solids content is of great importance in fruits for both fresh consumption and industrial processing, since high levels of these raw constituents imply less sugar addition, shorter water evaporation time, shorter energy expenditure and higher product yield; therefore, greater processing savings (Jesus, Matsuura, Folegatti, \& Cardoso, 2005).

The levels of total and reducing sugars found in this study are close to those obtained by Godoy et al. (2016), who stated $17 \%$ of total sugars and $18.33 \%$ of reducing sugars for bananas of the same cultivar at maturity stage 6 . According to Carvalho et al. (2011), sugar levels in fully ripe bananas range from 15 to $20 \%$. The sugar content in bananas is directly related to their taste, but also to shelf-life, since sugars are the main products of the glycolytic 
pathway, responsible to produce compounds that will later be used for respiration to produce ATP (Chitarra \& Chitarra, 2005). Nevertheless, fruits with higher sugar reserves tend to have longer shelflife.

\section{Conclusions}

$\mathrm{P}$ fertilizer increases $\mathrm{P}$ content in the unripe fruits of 'FHIA 18 ' banana until $100 \%$ of recommended dose $\left(40 \mathrm{~kg}\right.$ of $_{2} \mathrm{O}_{5}$ ha $^{-1}$ year $\left.^{-1}\right)$, as well as an increase in reducing sugar content when applied up to $61 \%$ of the recommended dose $\left(24.4 \mathrm{~kg}\right.$ of $\mathrm{P}_{2} \mathrm{O}_{5} \mathrm{ha}^{-1}$ year $\left.{ }^{1}\right)$ in the first production cycle.

In ripe fruits, $\mathrm{P}$ fertilizer allows to obtain fruits with less acidity and higher maturity index (TSS/ TTA ratio) at lower doses than recommended $(100 \%)$, i.e. $52-53 \%$ of the recommended $(21 \mathrm{~kg}$ of $\mathrm{P}_{2} \mathrm{O}_{5}$ ha $^{-1}$ year ${ }^{-1}$ ); thus, improving fruit flavour and then better consumer acceptance.

The contents of dry matter, starch and phosphorus in unripe fruits, as well as the firmness, total soluble solids, maturity index and sugar in ripe fruits increased from the first production cycle to the subsequent cycles, regardless of the applied $\mathrm{P}_{2} \mathrm{O}_{5}$ doses.

\section{Acknowledgment}

To the National Council for Scientific and Technological Development (CNPq) for their financial support (Processes 304455/2017-2, 303373/2014-8, 302827/2017-0).

\section{References}

Absar, N., Sarker, M. Z. I., Takigawa, S., Hashimoto, N., Matsuura-Endo, C., \& Yamauchi, H. (2009). Enzymatic hydrolysis of potato starches containing different amounts of phosphorus. Food Chemistry, 112(1), 57-62. doi: 10.1016/j.foodchem.2008.05.045

Adão, R. C., \& Glória, M. B. A. (2005). Bioactive amines and carbohydrate changes during ripening of
'Prata' banana (Musa acuminata x M. balbisiana). Food Chemistry, 90(4), 705-711. doi: 10.1016/j. foodchem.2004.05.020

Association of Official Analytical Chemists. (2007). Official methods of analysis of AOAC International. (18nd ed. Current Through Revision 2). Gaithersburg: AOAC.

Attia, M., Ahmed, M. A., \& El-Sonbaty, M. R. (2009). Use of biotechnologies to increase growth, productivity and fruit quality of 'Maghrabi' banana under different rates of phosphorus. World Journal of Agricultural Sciences, 5(22), 211-210.

Aular, J., \& Natale, W. (2013). Nutrição mineral e qualidade do fruto de algumas frutíferas tropicais: goiabeira, mangueira, bananeira e mamoeiro. Revista Brasileira de Fruticultura, 35(4), 1214-1231. doi: 10.1590/S0100-29452013000400033

Carvalho, A. V., Seccadio, L. L., Mourão, M., Jr., \& Nascimento, W. M. O. (2011). Postharvest quality of 'maça' banana cultivars in Belém Region-PA. Revista Brasileira de Fruticultura, 33(4), 10951102. doi: 10.1590/S0100-29452011000400007

Castricini, A., Santos, L. O., Deliza, R., Coelho, E. F., \& Rodrigues, M. G. V. (2015). Caracterização póscolheita e sensorial de genótipos de bananeiras tipo prata. Revista Brasileira de Fruticultura, 37(1), p. 27-37. doi: 10.1590/0100-2945-058/14

Chitarra, M. I. F., \& Chitarra, A. B. (2005). Pós-colheita de frutos e hortaliças: fisiologia e manuseio. (2a ed.) Lavras: Editora UFLA.

Companhia de Entrepostos e Armazéns Gerais de São Paulo. (2006). Programa brasileiro para a modernização da horticultura e produção integrada de frutas. Normas de classificação de banana. São Paulo: CEAGESP. (Documento, 29).

Cunha, A. R., \& Martins, D. (2009). Classificação climática para os municípios de Botucatu e São Manuel, SP. Irriga, 14(1), 1-11. doi: 10.15809/ irriga.2009v14n1p01

Damatto, E. R. D., Jr., Campos, A. J., Manoel, L., Moreira, C. M., Leonel, S., \& Evangelista, R. M. (2005). Produção e caracterização de frutos de bananeira 'Prata-Anã' e 'Prata-Zulu'. Revista Brasileira de Fruticultura, 27(3), 440-443. doi: 10.1590/S010029452005000300024

Ferreira, D. F. (2011). Sisvar: A computer statistical analysis system. Ciência e Agrotecnologia, 35(6), 1039-1042. doi: 10.1590/S141370542011000600001 . 
Godoy, R. C. B., Waszczynskj, N., Santana, F. A., Silva, S. O., Oliveira, L. A., \& Santos, G. G. (2016). Physico-chemical characterization of banana varieties resistant to black leaf streak disease for industrial purposes. Ciência Rural, 46(9), 15141520. doi: 10.1590/0103-8478cr20150905

Instituto Adolfo Lutz. (2008). Métodos físico-químicos para análise de alimentos. (4a ed). São Paulo: IAL.

International Organization for Standardization. (1987). Norme internationale: rizdétermination de la teneur em amylose. Genebra: ISO 66470.

Jane, J. (2006). Current understanding on starch granule structure. Journal of Applied Glycoscience, 53(3), 205-213. doi: 10.5458/jag.53.205

Jesus, S. C., Matsuura, F. C. A. U., Folegatti, M. I. S., \& Cardoso, R. L. (2005). Avaliação de banana-passa obtida de frutos de diferentes genótipos de bananeira. Pesquisa Agropecuária Brasileira, 40(6), 573-579. doi: 10.1590/S0100-204X2005000600007

Kurien, S., Kumar, P. S., Kamalam, N. V., \& Wahid, P. A. (2006). Intermat and intramat competition in banana studied using 32P. Fruits, 61(4), 225-235. doi: 10.1051/fruits:2006020

Leonel, M., Carmo, E. L., Leonel, S., Franco, C. M. L., \& Campanha, C. B. (2011). Extração e caracterização do amido de diferentes genótipos de bananeira. Revista Brasileira de Fruticultura, 33(special issue), 599-605. doi: 10.1590/S0100-29452011000500082

Li, Z. H., Gemma, H., \& Iwahori, S. (2002). Stimulation of 'Fuji' apple skin colour by ethephon and phosphorus-calcium mixed compounds in relation to flavonoid synthesis. Scientia Horticulturae, 94(1-2), 193-199. doi: 10.1016/S0304-4238(01)00363-6

Malavolta, E., Vitti, G. C., \& Oliveira, S. A. (1997). Avaliação do estado nutricional das plantas: princípios e aplicações. $2 \mathrm{a}$ ed. rev. e atual. Piracicaba: Potafos. 319 p.

Martuscelli, M., Di Mattia, C., Stagnari, F., Speca, S., Pisante, M., \& Mastrocola, D. (2016). Influence of phosphorus management on melon (Cucumis melo L.) fruit quality. Journal Science of Food and Agriculture, 96(8), 2715-2722. doi: 10.1002/ jsfa. 7390

Medeiros, P. V. Q., Andrade, G., Pereira, R. G., Mendonça, V., \& Fonseca, J., Neto. (2014). Produção e qualidade de frutos de mangueira 'Tommy Atkins' adubadas com superfosfato simples no município de Assú - RN. Brazilian Journal of Applied Technology for Agricultural Science, 7(3), 7-16. doi: 10.31413/ nativa.v7i5.7170
Mesquita, C. B., Leonel, M., Franco, C. M. L., Leonel, S., Garcia, E. L., \& Santos, T. P. R. (2016). Characterization of banana starches obtained from cultivars grown in Brazil. International Journal of Biological Macromolecules, 89(8), 632-639. doi: 10.1016/j.ijbiomac.2016.05.040

Mohamed, A., Xu, J., \& Singh, M. (2010). Yeast leavened banana-bread: formulation, processing, colour and texture analysis. Food Chemistry, 118(3), 620-626. doi: 10.1016/j.foodchem.2009.05.044

Mustaffa, M. M., \& Kumar, V. (2012). Banana production and productivity enhancement through spatial, water and nutrient management. Journal of Horticultural Sciences, 7(1), 1-28.

Nascimento, B. R., Jr., Ozorio, L. P., Rezende, C. M., Soares, A. G., \& Fonseca, M. J. O. (2008). Diferenças entre bananas de cultivares Prata e Nanicão ao longo do amadurecimento: características físicas e químicas e compostos voláteis. Ciência e Tecnologia de Alimentos, 28(3), 649-658. doi: 10.1590/S010120612008000300022

Neilsen, G. H., Neilsen, D., \& Toivonen, P. (2008). Annual bloom-time phosphorus fertigation affects soil phosphorus, apple tree phosphorus nutrition, yield, and fruit quality. Hortscience, 43(3), 885-890. doi: 10.21273/HORTSCI.43.3.885

Nelson, N. (1944). A photometric adaptation of the Somogyi method for the determination of glucose. Journal of Biological Chemistry, 153(2), 375-380.

Nomura, E. S., Cuquel, F. L., Damatto, E. R., Jr., Fuzitani, E. J., \& Borges, A. L. (2017). Fertilization with nitrogen and potassium in banana cultivars 'Grand Naine', 'FHIA 17' and 'Nanicão IAC 2001' cultivated in Ribeira Valley, São Paulo State, Brazil. Acta Scientiarum Agronomy, 39(4), 505-513. doi: 10.4025/actasciagron.v39i4.32919

Oliveira, A. P., Silva, J. E. L., Pereira, W. E., \& Barbosa, L. J. N. (2005). Produção de batata-doce e teor de amido nas raízes em função de doses de $\mathrm{P}_{2} \mathrm{O}_{5}$. Acta Scientiarum Agronomy, 27(4), 747-751. doi: 10.4025/actasciagron.v27i4.1342

Oliveira, D. A. S. B., Müller, P. S., Franco, T. S., Kotovicz, V., \& Waszczynskyj, N. (2015). Avaliação da qualidade de pão com adição de farinha e purê da banana verde. Revista Brasileira de Fruticultura, 37(3), 699-707. doi: 10.1590/0100-2945-176/14

Oliveira, O. C. G., Donato, S. L. R., Mizobutsi, G. P., Silva, J. M., \& Mizobutsi, E. H. (2013). Características pós-colheita de bananas 'Prata Anã' e 'BRS Platina' armazenadas sob refrigeração. Revista Brasileira de 
Fruticultura, 35(3), 891-897. doi: 10.1590/S010029452013000300028

Park, M. R., Baek, S. H., Reyes, B. G., Yun, S. J., \& Hasenstein, K. H. (2012). Transcriptome profiling characterizes phosphate deficiency effects on carbohydrate metabolism in rice leaves. Journal of Plant Physiology, Stuttgart, 169(2), 193-205. doi: 10.1016/j.jplph.2011.09.002

Pereira, M. C. T., Salomão, L. C. C., Santos, R. C., Silva, S. O., Cecon, P. R., \& Nietsche, S. (2015). Aplicação em pré-colheita de cloreto de cálcio no controle do despencamento natural dos frutos de bananeira 'FHIA-18'. Ciência Rural, 45(11), 1925-1931. doi: 10.1590/0103-8478cr20131457

Roque, R. L., Amorim, T. B., Ferreira, C. F., Ledo, C. A. S., \& Amorim, E. P. (2014). Desempenho agronômico de genótipos de bananeira no recôncavo da Bahia, Revista Brasileira de Fruticultura, 36(3), 598-609. doi: 10.1590/0100-2945-361/13

Rosen, C. J., Kelling, K. A., Stark, J. C., \& Porter, G. A. (2014). Optimizing phosphorus fertilizer management in potato production. American Journal of Potato Research, 91(2), 145-160. doi: 10.1007/ s12230-014-9371-2

Silva, A. C., Aroucha, E. M. M., Chaves, S. W. P., Medeiros, J. F., Paiva, C. A., \& Araújo, N. O. (2016). Efeito de diferentes doses, formas de aplicação e fontes de $\mathrm{P}$ na conservação de melancia sem sementes. Horticultura Brasileira, 34(4), 529-536. doi: $10.1590 / \mathrm{s} 0102-053620160412$

Silva, J. T. A., \& Rodrigues, M. G. V. (2013). Produção da bananeira 'Prata Anã' em função da aplicação de adubo fosfatado, em quatro ciclos. Pesquisa Agropecuária Brasileira, 48(6), 613-618. doi: 10.1590/S0100-204X2013000600006
Silva, L. P., F ., \& Moreira, A. (2005). Ensacamento de cachos na produção, maturação e qualidade dos frutos de bananeiras cultivadas no Estado do Amazonas. Acta Amazonica, 35(4), 411-416. doi: 10.1590/S0044-59672005000400004

Siqueira, C. L., Almeida, H. J., Serpa, M. F. P., Batista, P. S. C., \& Mizobutsi, G. P. (2017). Modified atmosphere together with refrigeration in the conservation of bananas resistant to black Sigatoka. Revista Ciência Agronômica, 48(4), 614-624. doi: 10.5935/1806-6690.20170071

Souza, M. E., Leonel, S., Martins, R. L., Segtowick, E. C. S. (2013). Caracterização físico-química e avaliação sensorial dos frutos de bananeira. Nativa, 1(1), 1317. doi: 10.14583/2318-7670.v01n01a03

Taiz, L., Zeiger, E., Møller, I. M., \& Murphy, A. (2017). Fisiologia e desenvolvimento vegetal. (6a ed.) Porto Alegre: Artmed.

Teixeira, L. A. J., Nomura, E. S., Damatto, E. R., Jr., \& Fuzitani, E. J. (2014). Banana. In A. T. E. Aguiar, C. Gonçalves, M. E. A. G. Paterniani, M. G. S. Tucci, \& C. E. F. Castro (Ed.), Instruções agrícolas para as principais culturas econômicas (7a ed. rev., pp. 46-51). Campinas: Instituto Agronômico. (Boletim Técnico, 200).

Zhao, Z., Shi, H. J., Wang, M. L., Cui, L., Zhao, H., \& Yun, Z. (2015). Effect of nitrogen and phosphorus deficiency on transcriptional regulation of genes encoding key enzymes of starch metabolism in duckweed (Landoltia punctata). Plant physiology and biochemistry, 86, 72-81. doi: 10.1016/j. plaphy.2014.11.007 
